\title{
COMPOSTING STRATEGY FOR DEVELOPING CITIES: A CASE STUDY OF BEIRA, MOZAMBIQUE
}

\author{
DARIO GUIRRERI ${ }^{1}$, SILVIA SILVESTRI ${ }^{2}$, ANDREA CRISTOFORETTI ${ }^{2}$, ISACCO RAMA ${ }^{3}$, \\ RAMONA GIUREA ${ }^{1}$, ELENA MAGARIL ${ }^{4} \&$ ELENA CRISTINA RADA $^{5}$ \\ ${ }^{1}$ Environmental and Mechanical Engineering, University of Trento, Department of Civil, Italy \\ ${ }^{2}$ Foundation Edmund Mach, Italy \\ ${ }^{3}$ Foundation CAM - Consortium of Associations with Mozambique, Italy \\ ${ }^{4}$ Department of Environmental Economics, Ural Federal University, Russian Federation \\ ${ }^{5}$ Department of Theoretical and Applied Science, University of Insubria, Italy
}

\begin{abstract}
This article aims to provide a contribution to the value and possibility of using composting as a tool for the treatment and management of the organic fraction of urban solid waste in developing contexts - specifically, the city of Beira, Mozambique. The aforementioned process should be intended not as an exhaustive tool but rather as a useful form of treatment to be employed within an Integrated Waste Management Plan. The high and diversified presence of materials suitable for the specific treatment in question is ascertained while also highlighting the diversification of the users that can be involved. Mixing strategies are drawn up in order to provide indications for a correct composition of the matrix that is intended to be started as a process and, according to the quantities considered (according to a modular approach), the production that can derive from it. A technical proposal is then drawn up on the functional areas making up the plant in order to develop the process in question. In addition to promoting the composting process itself, the article aims to valorize its final product, the compost, which in certain specific contexts, such as the one considered, can be useful or even necessary. Keywords: composting, developing countries, Mozambique, MSW management, organic waste.
\end{abstract}

\section{INTRODUCTION}

Waste Management is the second most important problem after water quality in developing countries and worldwide [1]-[8]. According to the United Nations Environment Programme (UNEP) [9] waste disposal is a relevant problem in the less developed countries due to the demographic increase, poverty and high rate of urbanization, all that combined with inefficiency and under-financing by Governments in providing an adequate strategy for the management of municipal solid waste (MSW) [10]-[14].

Factors such as waste composition, technologies and/or lack of infrastructures, have been recognized as basic elements to set up a good and sustainable MSW management in developed and developing countries [15]-[18]. Generally, in the developing countries the only form of final disposal is generally open landfills, which periodically develops uncontrolled combustion with the inevitable production of atmospheric pollution and leachate [19]-[25].

MSW generated in developing countries is characterized by a high density and high content of organic matter, few metals and plastics content [26]-[30]. Big problems refer to the inefficient facilities for MSW collection, low treatment technologies and presence of slums built in a random and unplanned manner with unavoidable problems of accessibility [31]-[35].

At national level, in Mozambique, the Decree No. 13/2006 introduces Waste Management Plans (WMP) and includes relevant rules, provides principles, objectives, tools and guidelines for an Integrated Solid Waste Management (ISWM) [36].

The city of Beira (Conselho Municipal da Beira - CMB), is making concrete efforts in improving provided services to citizens promoting an international partnership coordinated 
by Consortium of Associations with Mozambique (CAM). CMB has drafted the "Postura Municipal para a Gestão de Resíduos Sólidos", which aims not only to find management tools, but also to improve life conditions of population, in order to establish the sufficient conditions for a sustainable development.

The use of compost as a strategy for the management of the organic fraction of municipal solid waste (OFMSW), in Mozambique, it was already used in Maxixe [37]. Also, in Beira, composting has been identified as a possible method of OFMSW treatment, with a view to valorisation and reuse [38]. This article presents the results and proposals for the Beira case.

\section{MATERIALS AND METHODS}

Beira is the capital of the Sofala Province and the second city of Mozambique with a population of about half million of inhabitants. It represents the second industrial park and the third biggest seaport in Mozambique for the import-export flows. The city's economy is mainly based on trade and port activity and the commercial and transport sectors appear to be the most developed; a sector of equal importance is certainly represented by agriculture.

The MSW management is on the responsibility of the VGUE (Vereação de Gestão Urbana e Equipamentos). The current state presents several problems both with regard to the equipment available, their excessive use as well as an incomplete coverage of the service for the areas of the city. A weak link in the chain is precisely the collection service. There are three different systems forms of waste collection: contendores $\left(6 \mathrm{~m}^{3}\right)$, tambores $(200 \mathrm{~L})$ and direct arrangement on the ground. Container trucks, auto-compacting machines and tractors are the means used for the MSW collection, whose number of units is reduced, and the availability often not guaranteed. The final point of waste delivery, the municipal landfill, is not delimited and presents significant problems with regard to the access especially during the rainy period. The waste disposal is completely uncontrolled, so there are problems of both volumes and run-off; the landfill, as common in other developing contexts, presents the informal collection phenomena.

For the development of the present research, six sectors of different types of waste were considered (domestic, market waste, industrial, commercial, green street sweeping waste). The total daily production being about $523 \mathrm{t} / \mathrm{d}(190,822 \mathrm{t} / \mathrm{y})$. The domestic sector represents the major contribution, $65 \%$, followed by the market waste sector, $20 \%$ [38], [39].

In the context of Beira, different directions were taken that include a direct approach with local institutions, with managers and activities aimed at the quality-quantitative characterization of materials and/or the identification of spaces in order to combine all useful and necessary information to draft the project proposal for MSW management. The field work was divided into: identification of the matrices to be treated and their production points, transfer modes of the selected matrices, treatment plant, composting process and compost, intended destination.

Regarding the market and food wastes, data were collected together with VGUE. The percentage of organic matter $\left(100 \mathrm{~m}^{3} /\right.$ month) produced in these markets was identified through field analysis, direct comparisons with local responsibles and measurements of the apparent density of the waste were carried out in order to extrapolate the weight value of the effective quantity of organic matter produced. The characterization of waste from restaurants activities was conducted through questionnaires. The georeference of the restaurants was made in order to estimate the produced quantities of waste and its percentage of organic fraction (OF).

Thanks to the collaboration with VAPPMA (Vereação de Agro-Pecuária, Pescas e Meio Ambiente), and local responsibles, it was possible to retrieve data regarding the maintenance of the urban green waste (number of cropper trees), the pruned roads and the specifications 
relating to the operating conditions of the activities themselves (number of means used and their capacity). The average timber productions associated with a tree has been identified and has allowed the extrapolation of the average monthly production and maps have been drawn up to identify the urban areas undergoing maintenance.

Regarding seeping and sludge waste, data were obtained thanks to the collaboration with SASB (Servições Autónomos de Saneamento da Beira) and with ETAR (Estação de Tratamento de Águas Residuais). The investigative activity concerning this type of material was possible thanks to a comparison with the treatment plant manager, the direct vision of operations conducted inside the wastewater treatment station and the estimation of the apparent density of the sludge in order to extrapolate quantitative production at monthly scale. Furthermore, chemical analyses have been carried out on the sludge, which has ascertained the suitability for use in the composting process.

The proposed plant, for the above considered materials, is shown in Fig. 1. Compost market opportunities represent a crucial point in order to understand the potential use of the final product. The problem does not consist in identifying the intended use, but in the cost-benefit aspect, in order to make the entire supply chain economically sustainable.

Chemical analyses have been taken on soil samples of some countryside in the outlying areas of the city and investigation in theoretical form have been carried out additionally. As regard the cost-benefit analysis, realities possibly interested in the purchase of compost have been investigated and are worthy of further investigation. The first stage was the identification and selection of the available matrices that it was decided to use in the composting treatment (their quality-quantitative characterization being a nodal point).

In this paper the OFMSW considered to be sent in the composting plant was divided into two components: market and catering waste. Regarding the first one, the production of the two main urban markets of the city, Maquinino and Goto, have been evaluated.

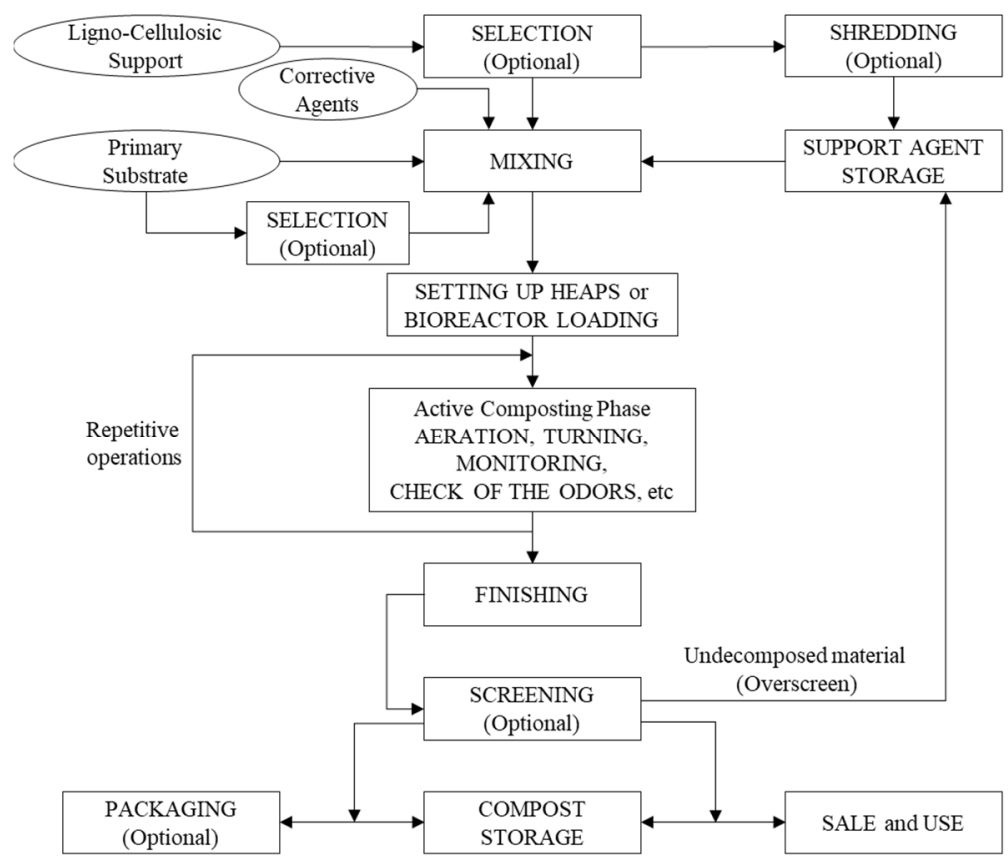

Figure 1: Flow chart of a composting plant. 


\section{RESULTS}

Thanks to the collaboration with local bodies and VGUE, VAPPMA, SASB, ETAR, CAM and $\mathrm{CMB}$, it was possible to obtained the determination of mass quantities, reported in Table 1, useful and necessary to draft the mixing plans.

The values reported have been time scaled, starting from the determination of the OFMSW production on daily basis (day of market) and considering the number of days of market along the year. Half of the containers considered in each market are also improperly used by citizens, so only those for use almost exclusively in the markets were taken into consideration: almost exclusively OFMSW was found with a low percentage of other materials $(15 \%)$.

Regarding the restaurant activities, a map was created in order to have a graphical representation of their spatial arrangement within the urban fabric. Among those surveyed, 20 , only half were taken in consideration. These are the major ones which presented at the same time a greater interest and willingness to collaborate. In Table 2, data regarding the OFMSW for the considered matrices are reported. The OFMSW quantities from these have a contribution of an order of magnitude lower than that of the markets but not less important for this reason. The reported data demonstrate also that it is essential to integrate and involve the users.

Regarding the lignocellulosic material to be used in the composition of the initial matrix, the green waste production was estimated considering the units undergoing maintenance, and the potential of the management service for urban green areas. A production range of $0.4-1.4 \mathrm{t} /$ tree has been assumed, considering the size and variability of the tree type. The average production value of each tree was considered 0,9 t. In Table 3 the production fluctuation during a year is reported.

In order to verify the values, the calculations were performed according to the number of working days (visible in Table 4), the number of means used daily (during maintenance operations) and their capacity.

Table 1: Production of potential organic matter (OM).

\begin{tabular}{|c|c|c|c|c|}
\hline \multirow{2}{*}{ Marketplace } & \multicolumn{2}{|c|}{ Total annual production OM } & \multicolumn{2}{c|}{ Total monthly production OM } \\
\cline { 2 - 5 } & $\left(\mathrm{m}^{3} / \mathrm{y}\right)$ & $(\mathrm{t} / \mathrm{y})$ & $\left(\mathrm{m}^{3} / \mathrm{month}\right)$ & $(\mathrm{t} / \mathrm{month})$ \\
\hline Maquinino & $5,875.2$ & $2,908.2$ & 489.6 & 242.4 \\
\hline Goto & $2,937.6$ & $1,454.1$ & 244.8 & 121.2 \\
\hline Total & $8,812.8$ & $4,362.3$ & 734.4 & 363.5 \\
\hline
\end{tabular}

Table 2: Quantitative production.

\begin{tabular}{|c|c|}
\hline \multirow{2}{*}{ Source } & Total monthly production O.M. \\
\cline { 2 - 2 } & $(\mathrm{t} / \mathrm{month})$ \\
\hline Market waste & 364 \\
\hline Restaurants & 11 \\
\hline
\end{tabular}


Table 3: Monthly lignocellulosic material production.

\begin{tabular}{|c|c|c|}
\hline Months & Pruned trees & Average production (t/month) \\
\hline January & 0 & 0 \\
\hline February & 145 & 130.5 \\
\hline March & 164 & 147.6 \\
\hline April & 176 & 158.4 \\
\hline May & 275 & 247.5 \\
\hline June & 345 & 310.5 \\
\hline July & 357 & 321.3 \\
\hline August & 294 & 264.6 \\
\hline September & 365 & 328.5 \\
\hline October & 410 & 369.0 \\
\hline November & 204 & 183.6 \\
\hline December & 50 & 45.0 \\
\hline
\end{tabular}

Table 4: Further estimate of potential quantities of lignocellulosic material.

\begin{tabular}{|c|c|c|c|c|}
\hline Period & Days & $\begin{array}{c}\text { Working days } \\
\text { (Theoretical) }\end{array}$ & $\begin{array}{c}\text { Theoretical } \\
\text { production }(\mathrm{t})\end{array}$ & $\begin{array}{c}\text { Assumed } \\
\text { production }(\mathrm{t})\end{array}$ \\
\hline $\begin{array}{c}\text { March to } \\
\text { August }\end{array}$ & 184 & 127 & $1,587.5$ & $1,587.5$ \\
\hline $\begin{array}{c}\text { September to } \\
\text { February }\end{array}$ & 181 & 124 & 1,550 & $1,162.5^{*}$ \\
\hline $\begin{array}{l}\text { January to } \\
\text { December }\end{array}$ & 365 & 251 & $3,137.5$ & 2,750 \\
\hline
\end{tabular}

Table 5: Amount of produced fresh and dried sludge.

\begin{tabular}{|c|c|c|c|c|}
\hline $\begin{array}{c}\text { Monthly sludge } \\
\text { production 1 }\end{array}$ & $\begin{array}{c}\text { Monthly sludge } \\
\text { production 2 }\end{array}$ & $\begin{array}{c}\text { Sludge } \\
\text { average } \\
\text { density 2 }\end{array}$ & $\begin{array}{l}\text { Monthly sludge } \\
\text { production 2 }\end{array}$ & $\begin{array}{l}\text { Daily sludge } \\
\text { production 2 }\end{array}$ \\
\hline$\left(\mathrm{m}^{3} /\right.$ month) & $\left(\mathrm{m}^{3} /\right.$ month $)$ & $\left(\mathrm{t} / \mathrm{m}^{3}\right)$ & $(\mathrm{t} /$ month $)$ & $(\mathrm{t} /$ month $)$ \\
\hline 27 & 13.5 & 0.694 & 9.4 & 0.310 \\
\hline $\begin{array}{l}1=\text { Fresh sludge leaving the anaerobic reactor; } 2=\text { Dried sludge leaving the drying beds } \\
\text { (arranged in cells) }\end{array}$
\end{tabular}

The sewage sludge (SS) production reported in Table 5, is very low due to the current operating conditions of the whole sanitation infrastructure. Data were given by ETAR. Once the availability of the different materials was known, using a modular approach, and establishing the initial input material as 1,500 t/y (125 t/month), it was possible to draw up a mixing plan on a monthly scale, that is reported in Table 6 . 
Table 6: Mixing strategy.

\begin{tabular}{|l|c|c|c|c|c|c|c|c|c|c|c|}
\hline \multirow{2}{*}{$\begin{array}{l}\text { Raw } \\
\text { material }\end{array}$} & Weight & Weight & A.D. & Vol. & Vol. & SS & SS & SS & N & C & C/N \\
\cline { 2 - 13 } & $(\mathrm{t} /$ month $)$ & $(\%)$ & $\left(\mathrm{t} / \mathrm{m}^{3}\right)$ & $\left(\mathrm{m}^{3}\right)$ & $(\%)$ & $(\%)$ & $(\mathrm{t})$ & $(\%)$ & & & \\
\hline OFMSW & 78.1 & 62.5 & 0.75 & 104.1 & 49.3 & 25 & 19.5 & 44.8 & 1.4 & 30 & 21.4 \\
\hline Sludge & 9.4 & 7.5 & 0.7 & 13.5 & 6.4 & 17 & 1.6 & 3.7 & 2.9 & 25 & 8.6 \\
\hline $\begin{array}{l}\text { Ligno- } \\
\text { cellulosic }\end{array}$ & 37.5 & 30 & 0.4 & 93.8 & 44.3 & 60 & 22.5 & 51.5 & 0.7 & 45 & 64.3 \\
\hline Total & 125 & 100 & 0.6 & 211.4 & 100 & 35 & 43.6 & 100 & 1.1 & 38 & 34.3 \\
\hline
\end{tabular}

Table 7: Compost quantities produced.

\begin{tabular}{|c|c|c|c|c|}
\hline COMPOST & Weight (t/y) & Volume $\left(\mathrm{m}^{3} / \mathrm{y}\right)$ & Weight (t/d) & Volume $\left(\mathrm{m}^{3} / \mathrm{d}\right)$ \\
\hline Raw & $675^{*}$ & $1,269 *$ & 3.2 & 6 \\
\hline Fine $^{2}$ & $450^{* *}$ & $923 * *$ & 2.1 & 4.4 \\
\hline 1 d downstream of the maturation phase; $2=$ downstream of the post-treatments \\
\hline * Raw Compost yield: $45 \%$ in Weight e $55 \%$ in Volume compared to the input quantity; \\
\hline ** Finished Compost yield: $30 \%$ in Weight e $40 \%$ in Volume compared to the input \\
\hline
\end{tabular}

The first phase of the process (accelerated bio-oxidation) is proposed to be carried in 3 cells and will be characterized by 21 days lasting (about 17-18 cycles/y). In each cell, about 29 tons of organic material by cycle can be treated. The aerobic conditions will be guaranteed by an insufflation system consisting of perforated corrugated tubes, a fan for the supply of air and one for suction. The exhausted process air will be sent to a bio-filter for its treatment before release into the atmosphere. This solution (used mainly from the mechanical biological treatment) is the most economic one and have a good pollutants removal efficiency [40]-[42]. Downstream of the accelerated bio-oxidation, a reduction in weight and in volume of $30 \%$ and $25 \%$ respectively, is was foreseen. In this way the quantity for the second phase is equal to $1,050 \mathrm{t} / \mathrm{y}\left(1,730.8 \mathrm{~m}^{3} / \mathrm{y}\right)$.

The second phase is carried out by placing the material on a stave along the linear-shaped piles. This area will represent the largest area inside the station. The maturation stage will be characterized by a duration of about 60 days for a total number of 6 cycles/year, about 173 tons/cycle will be treated. It has been hypothesized 4 piles, with a base and length of $3 \mathrm{~m}$ and $32 \mathrm{~m}$ respectively ( $384 \mathrm{~m}^{2}$ in plan covered with material in the secondary stabilization phase).

The piles are not aerated but they are subjected to turning operations thanks to a revolving machine, actuated and driven by the tractor, which plays a multifunctional role within the whole process. The wetting operations will be carried out by means of a rotary sprinkler located above the revolving machine. The overlapping of the two operations allows the optimization of the time-management aspect. In Table 7 the expected quantities of compost are reported.

For the OFMSW, a manual selection was considered for the removal of the bulkiest materials. For the brushwood, a bio-shredder was proposed. For the materials handling operations (mixing, heaps preparation and loading/unloading) a tractor with front blade can 
be used. At the end, a final screening trough a cylindrical roll was proposed. In this way, a homogenization of the material can be made but also will allow the recovery of any material not intercepted in the initial phases.

In Table 8 the surfaces needed for the proposed composting plant, considering the quantity of organic material that will be treated, are reported.

Given the above, the initial matrix value to be subjected to the treatment that was chosen to be considered is equal to $1,500 \mathrm{t} / \mathrm{y}$. This assumption, following the natural reductions that occur during the proposed process, would allow a production of about 450-675 t/y, depending on whether the compost is considered refined or raw, or downstream or upstream of the post-treatments (dimensional screening), which allow a higher final quality.

Regarding the possible use of compost, the first and simplified land analysis has highlighted that its application can be suitable with the existing land and will improve its physical, chemical and biological characteristics. Its use in the agricultural field can be made only after the development of a proper campaign of dissemination, promotion and demonstration, in order that compost will be considered a product of value.

\section{CONCLUSIONS AND PERSPECTIVES}

The study carried out, has allowed highlighting how the considered city, Beira, presents a high and diversified potential of suitable available materials for the biodegradation process such as composting. The main contribution in the organic material productions is certainly due to market utilities; also, the catering activities represents an important contribution in terms of quality and diversification of the commercial activities involved.

With regard to the wood-cellulosic material, used as the bulking agent, there is a significant quantity, as the city has numerous tree-lined avenues. It must be considered that in Mozambique, wood is widely used in domestic combustion for cooking purposes. The sewage sludge, is taken in consideration with a view to an integrated approach of the utilities and materials involved. Its involvement covers the additive function, however if SS characteristics become unsuitable, it is possible to implement a mixing plan without this element.

Table 8: Internal surfaces of composting plant.

\begin{tabular}{|l|l|c|}
\hline \multicolumn{2}{|c|}{ Areas } & $\begin{array}{c}\text { Surfaces } \\
\left(\mathrm{m}^{2}\right)\end{array}$ \\
\hline \multirow{3}{*}{$\begin{array}{l}\text { Receiving and pre-treatments } \\
\text { materials area }\end{array}$} & Green waste storage and shredding area & 200 \\
\cline { 2 - 3 } & Waste storage box & 25 \\
\cline { 2 - 3 } & Mixing box & 25 \\
\hline \multirow{3}{*}{ Active composting area } & 3 Cells & 75 \\
\cline { 2 - 3 } Maturation area & Biofilter & 5 \\
\hline & Heaps/windrow surface & 390 \\
\cline { 2 - 3 } & Lanes surface & 260 \\
\cline { 2 - 3 } $\begin{array}{l}\text { Post-treatments and storage } \\
\text { compost area }\end{array}$ & Operations surface & 200 \\
\hline Services area & Screening and storage compost area & 240 \\
\hline Total & Services local (/room) & 40 \\
\hline
\end{tabular}


Regarding the composting plant design, the choice to use a modular approach, i.e. to align the sizing to the quantity of input material established rather than the potentially available one, is configured as an evaluation tool for a successful project outcome. This, in fact, allows an analysis step by step of the real potential of using composting as an alternative to disposal in landfill, allowing a better understanding of the possible management limits and process difficulties on a small scale, minimizing the failure risk on a larger scale.

From a managerial point of view, for the success of the composting process, the logistic component must be taken into consideration by the personnel in charge. In this regard, the transmission and acquisition of adequate professional and managerial skills through a completed and iterated training is absolutely vital.

The composting process is capable of presenting its maximum effectiveness only within an ISWM. Composting is not and does not pretend to present itself as an absolute and exhaustive solution, but rather as an effective form of management of a given component of MSW, the biodegradable one.

In additional to the function of composting as a treatment form, the promotion of the "compost" use is important. This means that parallel projects that encourage the use of the product must be implemented. An example is the urban agriculture programs (agro-economy), which may prove capable of combining agricultural production activities for food purposes with the creation of useful spaces for the application of the obtained product, the compost (the country is currently undergoing strong timber exports).

Regarding the plant location, a crucial phase in the design of composting station, this remains a question not completely resolved within this study. Although some possible, suitable sites of the plant installation have been assessed, the selection of one rather than another must follows a careful and in-depth context analysis, also making use of geotechnical instruments. The choice, in addition to the various known criteria necessary to carry it out, should not be dictated by purely economic-financial issues in the short term. On the other hand, it cannot be exempt from careful assessments regarding medium/long-term, technical complications and burdens.

For the project implementation, at whatever scale it is carried out, a wide-ranging evaluation is absolutely necessary, which is capable of taking into consideration social, economic and environmental elements. It is essential, to not underestimate absolutely all those socio-educational and informative paths; that even if they seem apparently marginal, are fundamental ingredients for the success of the project, both from an acceptance and development point of view.

\section{REFERENCES}

[1] Serge Kubanza, N. \& Simatele, M.D., Sustainable solid waste management in developing countries: a study of institutional strengthening for solid waste management in Johannesburg, South Africa. Journal of Environmental Planning and Management, 63(2), pp. 175-188, 2020. https://doi.org/10.1080/09640568.2019.1576510.

[2] Ferronato, N., Torretta, V., Ragazzi, M. \& Rada, E.C., Waste mismanagement in developing countries: A case study of environmental contamination. UPB Scientific Bulletin, 79(3), pp. 185-196, 2017.

[3] Kiselev, A.V., Magaril, E.R. \& Rada, E.C., Energy and sustainability assessment of municipal wastewater treatment under circular economy paradigm. WIT Transactions on Ecology and the Environment, vol. 237, WIT Press: Southampton and Boston, pp. 109-120, 2019. https://doi.org/10.2495/ESUS190101. 
[4] Ragazzi, M., Rada, E.C., Torretta, V. \& Salazar-Valenzuela, X., Management of urban wastewater on one of the Galapagos Islands. Sustainability, 8(3), 208, 2016. https://doi.org/10.3390/su8030208.

[5] Nath, K.J. \& Sengupta, A.K., An alternative approach for municipal wastewater management: Technology options for small and medium towns. Water Practice \& Technology, 11(1), pp. 157-165, 2016. https://doi.org/10.2166/wpt.2016.001.

[6] Gallego-Schmid, A. \& Tarpani, R.R.Z., Life cycle assessment of wastewater treatment in developing countries: A review. Water Research, 153, pp. 63-67, 2019. https://doi.org/10.1016/j.watres.2019.01.010.

[7] Omwoma, S., Lalah, J.O., Kueppers, S., Wang, Y., Lenoir, D. \& Schramm, K.-W., Technological tools for sustainable development in developing countries: The example of Africa, a review. Sustainable Chemistry and Pharmacy, 6, pp. 67-81, 2017. https://doi.org/10.1016/j.scp.2017.10.001.

[8] Senkoro, H., Solid waste in Africa: A WHO/AFRO perspective. CWG Workshop: Solid Waste Collection That Benefits the Urban Poor, Dar es Salaam. https://scialert.net/fulltext/?doi=jest.2001.93.102. Accessed on: 10 Feb. 2020.

[9] UNEP, 2002 International Source Book on Environmentally Sound Technology for Municipal Solid Waste Management. (IETC) Technical Publication, USA. https://scialert.net/fulltext/?doi=jest.2001.93.102. Accessed on: 10 Dec. 2020.

[10] Rai, R.K., Bhattarai, D. \& Neupane, S., Designing solid waste collection strategy in small municipalities of developing countries using choice experiment. Journal of Urban Management, 8(3), pp. 386-395, 2019.

https://doi.org/10.1016/j.jum.2018.12.008.

[11] Ikhlayel, M., Development of management systems for sustainable municipal solid waste in developing countries: a systematic life cycle thinking approach. Journal of Cleaner Production, 180, pp. 571-586, 2018.

https://doi.org/10.1016/j.jclepro.2018.01.057.

[12] Aleluia, J. \& Ferrão, P., Assessing the costs of municipal solid waste treatment technologies in developing Asian countries. Waste Management, 69, pp. 592-608, 2017. https://doi.org/10.1016/j.wasman.2017.08.047.

[13] Kerdsuwan, S., Laohalidanond, K. \& Jangsawang, W., Sustainable development and eco-friendly waste disposal technology for the local community. Energy Procedia, 79, pp. 119-124, 2015. https://doi.org/10.1016/j.egypro.2015.11.493.

[14] Ragazzi, M., Catellani, R., Rada, E.C., Torretta, V. \& Salazar-Valenzuela, X., Management of municipal solid waste in one of the Galapagos islands. Sustainability, 6(12), pp. 9080-9095, 2014. https://doi.org/10.3390/su6129080.

[15] Han, Z. et al., Influencing factors of domestic waste characteristics in rural areas of developing countries. Waste Management, 72, pp. 45-54, 2018.

https://doi.org/10.1016/j.wasman.2017.11.039.

[16] UNESCO and sustainable development. http://unesdoc.unesco.org/images/0013/ 001393/139369e.pdf. Accessed on: 10 Dec. 2020.

[17] Kattoua, M.G., Al-Khatib, I.A. \& Kontogianni, S., Barriers on the propagation of household solid waste recycling practices in developing countries: State of Palestine example, Journal of Material Cycles and Waste Management, 21(4), pp. 774-785, 2019. https://doi.org/10.1007/s10163-019-00833-5.

[18] Rada, E.C. \& Cioca, L., Optimizing the methodology of characterization of municipal solid waste in eu under a circular economy perspective. Energy Procedia, 119, pp. 72-85, 2017. https://doi.org/10.1016/j.egypro.2017.07.050. 
[19] Sharma, G. et al., Gridded emissions of CO, NOx, SO2, CO2, NH3, HCl, CH4, PM2.5, PM10, BC, and NMVOC from open municipal waste burning in India. Environmental Science and Technology, 53(9), pp. 4765-4774, 2019.

https://doi.org/10.1021/acs.est.8b07076.

[20] Aleluia, J. \& Ferrão, P., Characterization of urban waste management practices in developing Asian countries: A new analytical framework based on waste characteristics and urban dimension. Waste Management, 58, pp. 415-429, 2016. https://doi.org/10.1016/j.wasman.2016.05.008.

[21] Ziraba, A.K., Haregu, T.N. \& Mberu, B., A review and framework for understanding the potential impact of poor solid waste management on health in developing countries. Archives of Public Health, 74(1), 55, 2016. https://doi.org/10.1186/s13690-016-0166-4.

[22] Dladla, I., Machete, F. \& Shale, K., A review of factors associated with indiscriminate dumping of waste in eleven African countries. African Journal of Science, Technology, Innovation and Development, 8(5-6), pp. 475-481, 2016. https://doi.org/10.1080/20421338.2016.1224613.

[23] Nagpure, A.S., Ramaswami, A. \& Russell, A., Characterization the spatial and temporal patterns of open burning of municipal solid waste (MSW) in Indian cities. Environmental Science and Technology, 49(21), pp. 12911-12912, 2015. https://doi.org/10.1021/acs.est.5b03243.

[24] Vithanage, M., Wijesekara, S.S.R.M.D.H.R., Siriwardana, A.R., Mayakaduwa, S.S. \& Ok, Y.S., Management of municipal solid waste landfill leachate: A global environmental issue. Environmental Deterioration and Human Health: Nat Anthropog Determ, pp. 263-288, 2014. https://doi.org/10.1007/978-94-007-7890-0_11.

[25] Cocarta, D.M., Rada, E.C., Ragazzi, M., Badea, A. \& Apostol, T., A contribution for a correct vision of health impact from municipal solid waste treatments. Environmental Technology, 30(9), pp. 963-968, 2009. https://doi.org/10.1080/09593330902989958.

[26] Dos Muchangos, L.S., Tokai, A. \& Hanashima, A., Application of material flow analysis to municipal solid waste in Maputo City, Mozambique. Waste Management and Research, 35(3), pp. 253-266, 2017. https://doi.org/10.1177/0734242X16678067.

[27] Intharathirat, R., Abdul Salam, P., Kumar, S. \& Untong, A., Forecasting of municipal solid waste quantity in a developing country using multivariate grey models. Waste Management, 39, pp. 3-14, 2015. https://doi.org/10.1016/j.wasman.2015.01.026.

[28] Villalba, L., Donalisio, R.S., Cisneros Basualdo, N.E. \& Noriega, R.B., Household solid waste characterization in Tandil (Argentina): Socioeconomic, institutional, temporal and cultural aspects influencing waste quantity and composition. Resources, Conservation and Recycling, 152, 104530, 2020. https://doi.org/10.1016/j.resconrec.2019.104530.

[29] Nagpure, A.S., Assessment of quantity and composition of illegal dumped municipal solid waste (MSW) in Delhi. Resources, Conservation and Recycling, 141, pp. 54-60, 2019. https://doi.org/10.1016/j.resconrec.2018.10.012.

[30] Ramesh, N., Meenambal, T., Vennila, G. \& Ramesh, S., Start up, operations and monitoring of upflow anaerobic sludge blanket (UASB) reactor for the treatment of organic fraction of Municipal solid waste. Ecology, Environment and Conservation, 22, pp. S319-S322, 2016.

[31] Ferronato, N., Preziosi, G., Gorritty Portillo, M.A., Guisbert Lizarazu, E.G. \& Torretta, $\mathrm{V}$., Assessment of municipal solid waste selective collection scenarios with geographic information systems in Bolivia. Waste Management, 102, pp. 919-931, 2020. https://doi.org/10.1016/j.wasman.2019.12.010. 
[32] Makarichi, L., Kan, R., Jutidamrongphan, W. \& Techato, K.-A., Suitability of municipal solid waste in African cities for thermochemical waste-to-energy conversion: The case of Harare Metropolitan City, Zimbabwe. Waste Management and Research, 37(1), pp. 83-94, 2019. https://doi.org/2019. 10.1177/0734242X18804029.

[33] Azevedo, B.D., Scavarda, L.F. \& Caiado, R.G.G., Urban solid waste management in developing countries from the sustainable supply chain management perspective: A case study of Brazil's largest slum. Journal of Cleaner Production, 233, pp. 13771386, 2019. https://doi.org/10.1016/j.jclepro.2019.06.162.

[34] Mohee, R., Mauthoor, S., Bundhoo, Z.M.A., Somaroo, G., Soobhany, N. \& Gunasee, S., Current status of solid waste management in small island developing states: A review. Waste Management, 43, pp. 539-549, 2015. https://doi.org/10.1016/j.wasman.2015.06.012.

[35] Brueckner, J.K., Slums in developing countries: New evidence for Indonesia. Journal of Housing Economics, 22(4), pp. 278-290, 2013. https://doi.org/10.1016/j.jhe.2013.08.001.

[36] Waste Management Plan. Mozambique LNG. www.mzlng.com/content/documents/ MZLNG/EIA/Volume_III/English/Annex_E_-_LNG_Final_EIA_Sept_2014 Eng.pdf. Accessed on: 10 Jan. 2020.

[37] Perteghella, A. \& Vaccari, M., Organic waste valorization through composting process: A full-scale case study in maxixe, Mozambique. Environmental Engineering and Management Journal, 16(8), pp. 1819-1826, 2017.

[38] CAM - Consorzio Associazioni con il Mozambico (Consortium of Associations with Mozambique), 2017. Campagna di Analisi Merceologica del Rifiuto Solido Urbano Domestico per la Città di Beira (Campaign of Commodity Analysis of Domestic Urban Solid Waste for the City of Beira). www.trentinomozambico.org/chi.html. Accessed on: 10 Dec. 2020.

[39] CAM - Consorzio Associazioni con il Mozambico (Consortium of Associations with Mozambique), 2017, Progetto di supporto tecnico al CMB nel settore dei RSU, Report sui Mercati cittadini che producono RSU - Organico (Project of technical support to the CMB in the sector of MSW, Report on City Market that certified MSW - Organic). www.trentinomozambico.org/chi.html. Accessed on: 10 Dec. 2020.

[40] Reyes, J. et al., Environmental performance of an industrial biofilter: Relationship between photochemical oxidation and odorous impacts. Environmental Research, 183, 109168, 2020. https://doi.org/10.1016/j.envres.2020.109168.

[41] Schiavon, M., Ragazzi, M., Torretta, V. \& Rada, E.C., Comparison between conventional biofilters and biotrickling filters applied to waste bio-drying in terms of atmospheric dispersion and air quality. Environmental Technology, 37(8), pp. 975982, 2016. https://doi.org/10.1080/09593330.2015.1095246.

[42] Cordova, T., Goodwin, J., Card, T. \& Schmidt, C.E., Possitive air, biofilter cover layer control biosolids composting emission. BioCycle, 56(3), pp. 49-51, 2015. 